\title{
Philosophy and Culture as Quest for Global Peace
}

\section{Oluwadare Abiona Akeju, Taiwo Martins Ayedero, Joseph Olurotimi Fasoro}

Faculty of Arts, Department of Philosophy, Ekiti State University, Ado-Ekiti, Nigeria

\section{Email address:}

akeju5656@gmail.com (O. A. Akeju), martinsayedero@gmail.com (T. M. Ayedero), rotimifasoro@gmail.com (J. O. Fasoro)

\section{To cite this article:}

Oluwadare Abiona Akeju, Taiwo Martins Ayedero, Joseph Olurotimi Fasoro. Philosophy and Culture as Quest for Global Peace. International Journal of Philosophy. Vol. 7, No. 4, 2019, pp. 151-159. doi: 10.11648/j.ijp.20190704.13

Received: June 24, 2019; Accepted: November 6, 2019; Published: November 12, 2019

\begin{abstract}
How can we enhance global peace through philosophy and culture? This question is very relevant to the contemporary world given the crises situation of world peace and the challenge of using philosophy and culture to enhance global peace. This paper is of the view that the crises being witnessed in the world can be alleviated if there is a concerted examination and understanding of philosophy and culture since crises or wars pervading the world are products of culture. But the praxis of enhancing global peace needs the theoretical and systemic examination of culture and philosophy. Peace is a necessary catalyst for the overall development of human existence. This paper, therefore, argues that philosophy and culture can be used to enhance world peace if they are taken as two basic principles guiding the conception of peace are strictly understood and adhered to. But do people have a political and philosophical culture that will promote the enhancement of global peace? The systematic analysis of philosophy and culture reveals that they could be used as theoretical and critical tools for the realization of global peace. The paper, therefore, advocates for a complete reorientation of humans in philosophy and culture as capable of promoting global peace since a proper understanding of philosophy and culture will enable human beings, especially world leaders, to be genuine participants in promoting global peace.
\end{abstract}

Keywords: Philosophy, Culture, Peace, Governance, Terrorism, Impunity

\section{Introduction}

How can we promote global peace which we consider to be the essential condition for human development and existence using philosophy and culture as essential tools for the stability and sustainability of peace in the world? This question is being raised because peace is germane to human development especially in the contemporary age of science information and computer technology.

Many studies on the problem of global peace have not been done using philosophy and culture as sustainable tools. It is in recognition of this fact that this paper seeks to reflect critically on how philosophy and culture can be entrenched to enhance global peace. We will also submit that philosophy is a product of culture and it (philosophy) must serve human existence and development in terms of enhancing global pace. Otherwise, any claim on culture and philosophy as tools to enhance global peace will be a mere pretension.

Our position shall be that despite the scorn for philosophy due to its abstract and abstruse nature, people do not know the avowed importance of philosophy to human existence, especially world peace.

The paper shall further examine why world leaders do not have a reflective perception on culture and philosophy, and why the contemporary leaders do not make use of the ideas of philosophers or involve them in governance, as the reason why peace is eluding many parts of the world. The words of Plato are relevant here. He says: "There will be no peace in the world unless philosophers become rulers or rulers become philosophers" [1]. If the world leaders could have genuine knowledge and understanding of philosophy and culture, they will be capable of using the ideas and ideals of philosophy/philosophers and culture to sustain global peace.

Philosophy, culture, and peace have the whole of (philosophical, cultural and peaceful) realities as their ultimate object of thought and reflections. Philosophy, due to its critical tool and reflective prowess, systematically probes into cultural beliefs and realities of human beings in different epochs and climes to enhance peaceful human existence.

The other salient objective of the paper is to reduce the tension created among thinkers when mention is made of the relation among philosophy, culture, and peace. In this light, the proper task of a philosopher should be that of criticism, 
exposition, analysis and systematic reconstruction of the triad of philosophy, culture, and peace which our attempt is focused upon here in order that the knowledge of philosophy, culture, and peace gained will be geared towards the improvement of world peace and human existence.

\section{Method}

Essentially, the paper adopts a systematic theoretical discourse methodology. Therefore, the approach is reflective and analytic. It begins with a critical analysis of the concepts: philosophy, culture, and peace, and how they can be used in enhancing global peace. Besides, for a proper elucidation and better understanding, the paper examines philosophy, culture, and peace from the critical and systematic prescriptive perspective. The method and style adopted in the paper are theoretically penetrating, conceptually suitable and practically useful given the abstractness of the themes of the discourse. The straight forward analytic and critical guide largely explains the non-technical language style of the paper.

\section{Conceptualizing Philosophy, Culture, and Peace}

\subsection{Philosophy}

The problem of philosophy, as an enterprise, begins at the level of conceptualization. Thinkers or philosophers who have discussed the concept of philosophy have expressed the problem that arises in the attempt of defining it (philosophy). For instance, philosophy is difficult to define because of its ideological interpretations. The ideological struggle among the empiricists, rationalists, idealists, materialists, positivists, existentialists, etc., makes them conceive and define philosophy differently.

The main point we are trying to make is that the meaning that an individual thinker/philosopher accords philosophy is a product of his epochal and ideological orientation since philosophers philosophize based on their epochal and geographical milieu.

Our position here is that if philosophy is not properly defined in the way that is meaningful to people, especially to world leaders, they 'will live in an inextricable confusion of ideas' of what philosophy is and its avowed importance is to humans. Hence, we shall attempt some definitions of the concept philosophy before those of culture and peace.

\subsubsection{Some Definitions Philosophy}

Philosophy is a product of what people say" i.e. a product of their thought. This assertion makes philosophy a complex term to define since thinkers live(d) in various epochs and view(ed) philosophy differently based on their experiences. However, we will reflect on what scholars or thinkers said (say) on philosophy in terms of its definition and meaning. This is expected to make this paper meaningful and understandable, especially when the avowed roles of philosophy and philosophers to peaceful human existence are expounded in this study.

Philosophy is an essential tool used to find peaceful solutions to the problems of experience and transcendental entities which perplex human beings. From the ancients, some thinkers believe that philosophy helps towards a better understanding of natural and cultural weird events, beliefs, and phenomena like birth and death, day and night, eclipse, drought, reincarnation, efficacy of incantations, appearance and reality, permanence and change, and other phenomena things which are the constituents of conflicts, strifes, wars that inhibit peaceful cohabitation of human beings in the world. Man pondered on the phenomenal weird events rationally to find solutions to the problems of the events which perplexed humans. The essence of man's rationality is philosophical since rationality involves deep reflection.

Historically and etymologically, philosophy in the West is derived from two Greek words, philein or philo to love, and Sophia wisdom [1]. In the Euthydemus, Plato defines philosophy as the "acquisition of knowledge" [2]. In another work Charmides [1], Plato defines philosophy as "the only science which is the science itself and that of the other sciences as well" [2].

According to René Descartes, philosophy does not spring from reasons of utility, neither does it flourish out of caprice... [3]. It is constitutionally necessary to the intellect. Its purpose is to seek all things as such, to capture the universe. Hence, philosophy becomes the knowledge of the universe or of whatever there is, and what transcends human experience. The famous American pragmatic philosopher, John Dewey, conceives philosophy as the "criticism of criticisms" [4]. This succinct description of philosophy by Dewey tells us that philosophy is an inquiry about inquiries. Furthermore, while giving philosophy a social function, Dewey defines it as a vision whose function is “to free man's mind from bias, and prejudices and to enlarge his perception of the world about him" [4].

Wittgenstein, an analytic and linguistic 20th Century philosopher, states that philosophy "aims at the logical clarification of thought"[5]. The American pragmatic philosopher, William James, defines philosophy as "the principles of explanation that underlies all things without exemption, the elements common to gods and men and animals and stones, the first whence and the last whither of the whole cosmic procession, the conditions of all-knowing, and the most general rules of human conduct"[6]. Joad defines philosophy lucidly, thus: philosophy is, "I think, most appropriately to be conceived as a clearinghouse to which the results of all other human inquiries are brought and in which the records of all forms of human experience are sifted, assessed and evaluated"[7].

From the above definitions of philosophy, it may be deduced that philosophy can be described as the critical consciousness of people at a particular time of their development. Similarly, philosophy is the study of the fundamental problems of reality, truth, values, and reasoning. This kind of definition summarizes the key concerns in the 
four main traditional branches of philosophy. Thus Metaphysics is the study of ultimate reality. The main concern of Epistemology, or Theory of Knowledge, is truth, that of Ethics is values while Logic is concerned with the study of correct reasoning. That is, the above definitions of philosophy refer to one common element, and that is "love of wisdom", or the "pursuit of wisdom", for all the philosophers were, and still are after authentic wisdom.

For a philosopher to have a comprehensive rational survey of the universe, and for him to make a critical independent objective investigations, he must have the understanding of philosophies of history, law, science, art, economics, religion, and philosophy (itself), as forms of human rational activity or modes in which the human spirit comes to an awareness of its potentialities. For the above reason, when the question of understanding the general nature of man and humans, society, peaceful human existence, and transcendental entities arises, men must turn to the study of culture, peace, and philosophy and take shelter. Therefore, the avowed function of philosophy today is to help a man in his understanding of the universe in terms of the total reality and peaceful world. This may be the reason why Dale Jacquette argued that "philosophy is at once a forward-looking search for understanding, enlightenment, and truth that remains constantly in dialogue with its history" [8].

In the contemporary world, philosophy is seen as an 'activity', of logical analysis and elucidation of weird concepts or expressions yearning for clarity and meaningfulness, and 'culture' and peace" are the concepts that need logical analysis for it to be meaningful. Thus, philosophy is related to culture and peace in terms of their elucidation. The fact that philosophy employs an analytic method in its quest for clarity of concepts and expressions, and answering questions, in a peaceful atmosphere, that may be the reason why Olatunbosun argues that:

Philosophy is quite different from other fields of study. It is unique both in its methods and in the nature and breadth of its subject-matter. Philosophy pursues questions in every dimension of human life, and its techniques apply to problems in any field of study and endeavor [9].

Having enunciated some of the definitions of philosophy, let us discuss some of the avowed roles of philosophy to peaceful human existence before we examine what culture is.

\subsubsection{The Role of Philosophy to Human Existence}

If philosophy is concerned with rationality, and human beings are known to be rational animals, philosophy should be used to solve human problems, especially those which pertain to peaceful human existence. Science, politics, education, computer information, and technology, etc., are what they are today, to a considerable extent, through the influence of philosophy. For instance, in politics, the idea that no man should be treated only as a means, or that government, should depend on the consent of the governed is owed originally to philosophers.

Similarly, John Locke's ideas expressed in the Second Treatise of Civil Government were the main influence behind the political philosophy of the founders of the American and the French Republics. A careful study of the Declaration of Independence and the American Constitution both have the following phrases lifted from Locke's Second Treatise of Civil Government: that 'all men are created equal,' and '... life, health, liberty, or possessions' are the essential needs of human beings [10]. Thus the political ideas of philosophers expressed and imbibed honorably by the American and French people in their constitutions are making democracy thrive or work in their countries today.

Philosophers philosophize to examine life critically and improve on peaceful human existence. For instance, Socrates, when he was being tried in 399 B.C.E., emphatically declared that the reason for philosophizing was that: "It is the greatest good for a man to discuss virtue every day and those other things about which you hear me conversing and testing myself and others, for the unexamined life is not worth living" [11]. In contemporary society, many people spend their time and lives pursuing various goals, like fame, riches, positions, etc., through sharp corrupt practices, pleasure and so on without ever asking themselves whether those goals or things are important. Philosophy becomes more relevant here because knowledge of philosophy is expected to enable human beings to ask the question: "Is unexamined life worth living?" If people examine their lives philosophically, they would not be enmeshed in corrupt practices like looting the treasuries or cause wars that would jeopardize peace. The common conviction of philosophers is the thoughtful examination and critical analysis of human views and beliefs. Philosophy makes a rational man reflect on the basic foundations of his outlook, his understanding, his knowledge, and his beliefs.

Like the scientists, philosophers are equally relevant to human existence in the contemporary society, in the sense that "while scientists conclude from empirical observations of the world, philosophers use rational arguments (and reflection) to justify claims about the world. For instance, John Locke claims that both scientists and philosophers are involved in contemporary studies and discourse on the concept of the human mind" [10].

Furthermore, "philosophers are also involved in cognitive science, trying to discover just what would count as discovering that dreaming is nothing more than certain electrochemical events in the brain" [11]. Cognitive questions about the brain which a scientist cannot answer properly are dealt with by philosophers. In contemporary society, "economists study the distribution of wealth... and develop theories about how wealth and other goods can be distributed... However, questions about which kind of distribution is juster, which kind of society is best to live in, are not answered within economic theory, these are philosophical questions [11].

Philosophy answers questions that perplex human beings. For instance, while medical professionals are concerned with facts about sickness and death, philosophers examine or try to find answers to questions about the phenomenon of death by asking various questions, such as: Can people survive 
their deaths if death is the separator of mind and body? Is death harmful to the person who dies? Under what circumstances can a person be assisted to commit suicide? etc.

Philosophy is relevant to human existence more than other disciplines because philosophy, or the philosopher, uses different techniques of investigation to solve problems of human existence in all ramifications. Philosophy employs the use of conceptual or linguistic analysis to clarify weird ideas and beliefs by supplying answers to the questions raised about them. Hence, "philosophy ferrets out; hidden assumption, objections where necessary and proffer alternatives to any given positions wherever required" [12]. This is why philosophy reflects and clarifies obscure ideas or concepts since the object of philosophy is to express meaning lucidly.

Training in philosophy is like medication for headache which sharpens man's brain and puts him in the right frame of mind. Therefore, the knowledge gained in philosophical studies helps to stimulate one to think and argue critically to improve peaceful human existence. Besides, the acquisition of a university degree in philosophy is an added advantage in providing a solid foundation for a career in a variety of other disciplines such as education, law, mass- communication, (particularly in print and electronic media), and administration.

While enunciating the roles of philosophy to humans, Makinde writes:

Philosophical ideas and reason have shaped the world from the ancient Greek philosophers, through Francis Bacon, John Locke, Immanuel Kant, J. S. Mill, Rene Descartes, Bertrand Russell, Isaac Newton, Albert Einstein, Karl Popper and many other philosophers who had written on Liberty and Freedom, Democracy and Representative government, Socialism and Communism, Justice and Anarchy. Many of these philosophers, notably the scientifically minded philosophers (Russell and Popper) and philosophically minded scientists (Newton and Einstein) have propounded philosophical and scientific ideas and theories that have shaped the course of science, technology, politics, and society [13].

It can be deduced from the above views, expressed by Makinde, that philosophy, or the philosophers and their ideas should be studied properly for understanding to adapt them (ideas) in revolutionizing the course of peace in human society, politics, and governance to improve the quality of human existence.

Philosophy teaches that knowledge is preferred to ignorance. Knowledge enables human beings to know the why, whence and whereof of things. Hence, Plato remarks: "Knowledge is a virtue and an effective instrument (endowment) to illuminate the dark abyss of ignorance". Therefore, the knowledge of philosophy enables man to live a peaceful and worthy life. This seems to have informed the thinking of Ogundowole, who while reflecting on the contemporary function of philosophy, writes "...[14] the function of philosophy is to liberate the mind, mold the man, shape his values and orientation, to be able to become more aware of his needs and improve his life in the society" [14]. At this juncture, we will like to conclude this section of the relevance of philosophy to peaceful human existence with these words of Omoregbe:

The training of the mind to see things critically and to seek the meaning and intelligibility of things is an important aspect of the development of the human person. This is part of the contribution of philosophy to the development of the human person. This critical approach to things which philosophy creates in man helps to acquire the right sense of value and the right attitude to peaceful resolutions of conflicts and wars [15].

The next focus is the systematic examination of the concept 'culture'. What is culture?

\subsection{Culture}

The concept of 'culture' has been constructed differently by thinkers and scholars. Hence, the attempt here is to examine some of their definitions to reconstruct the proper meaning of culture and relate it to peaceful human existence in the contemporary world. Before the examination of the definitions of culture let us trace the etymological origin of the term 'culture'. "The word 'culture' has its root in the Latin word colere which means 'to cultivate' [16]. Therefore, the word 'culture' means "the ideas, beliefs, and customs that are shared and accepted by the people in a society" [16]. Also, culture can be likened to the "idea of cultivating one's self to attain the ideal of wisdom which was found in Greek thought: the idea through which human beings become themselves" [17].

With this background-origin of the word "culture", let us examine some of the definitions of culture. It is not easy to define culture accurately because words cannot be used to describe the exact facts of cultural phenomena. However, men have played on words to define what culture is. Sir Edward Burnett Tylor, a British anthropologist was the first scholar to use the concept culture to "indicate the condition of a group of people" [18]. Tylor writes: Culture or cultivation taken in its wide ethnographic sense is that complex whole which includes knowledge, belief, art, morals, law, custom and any other capabilities and habits acquired by man as a member of society.

The Tylor's view on culture, in the above quotation, reflects the layman's definition of culture as the 'totality of the way of life of a group of people within a geographically defined area for a while'. That is, the way the people speak, dress, worship, celebrate a wedding, what and how they eat, etc. Therefore, culture may be said to be dynamic because the society of a group of people living together for a while is bound to change. This view may be in agreement with the sociological view that 'society is a change and change is society' [18].

Without men (human beings) the concept of 'culture' will not be expressed and interpreted. Thus, culture may be defined as the "human interpretation, expressed in meanings and values, philosophy, religion, and art of the purposes of 
life and society" [18]. This means that culture inevitably includes the material organization of social life in a society.

Again, to Kroeber (1948), culture is "the mass of learned and transmitted motor reactions, habit, techniques, ideas and values and the behavior they include". Ukpokolo in one of his writings referred to Bodley (1951) who defined the term 'culture' to refer to collectively to a society and its way of life or about human culture as a whole [17]. According to Abraham:

The word 'culture' is variously used. At its most inclusive, it is used to cover every possible aspect, public and private, of the life of a people. Used in this way, the term includes the whole of knowledge, the arts, science, technology, religions, morality, ritual, politics, literature, even etiquette and fashions, and such things as whether people clean their teeth three times a day or once [19].

Still, on the definition of culture, Ademowo quoted Ngugi wa Thiongo (1987) as defining culture as "a community's structure of values, the basis of their world outlook and how they see themselves and their place in the universe and with other communities" [20]. With the definitions of culture enunciated above, the identifying elements can be stated as follows:

i. Culture is the totality of the way of life of a people

ii. Culture is the legacy which the individual acquires from his milieu

iii. Culture is not a static but dynamic element in the society

iv. Culture includes the material organization of social life in a society

v. Culture involves the use of language in interpreting culture

vi. In cultural milieu, the key elements are language, norms, sanctions, and values.

If all these common elements of the definitions of culture are accepted as providing a truly meaningful knowledge of culture, then, let us examine the relationship between cultures and philosophies.

\subsubsection{Cultures and Philosophies}

Here, it must be borne in mind from the outset that cultures develop at different places and paces throughout the world. This equally applies to philosophies. According to Udo Etuk,

...it cannot be denied that cultures develop at different paces., some coming in contact with other civilizations at earlier points in history than others. The Greeks of the 6th century B.C. thought they were the first to do philosophy; whereas the ancient Chinese had been doing philosophy for some six centuries before them. Some cultures were even prevented from following the normal pattern of their development by the intrusion of people from other cultures [21].

With the above background, Etuk says, slave-trade introduced by Europeans robbed many West African countries of their able-bodied men (in millions) who would have contributed immensely to the development of their own cultures. Nature has provided 'features' for the survival of people in different cultural milieu throughout the world. If it were possible to draw a cultural map of the world, it would be seen that many cultures dotted the map of the world. What is germane to all cultures are in the areas of arts, language, philosophy, mode of worship, dressing, marriage, drumming, and so on.

One other thing about cultures is the uniqueness of each culture in terms of what it can contribute to the global culture and peace. The point being made here is stressed by Louis Luzbetak who thinks that "one of the commonest pitfalls in any cross-cultural activity to lose sight of (is) the uniqueness of (each) culture. Every design for a living has, so to speak, a personality or individuality of its own" [22].

\subsubsection{Influence of Culture on Philosophy}

What could be gleaned from the above view is that "philosophy and philosophers are influenced by the cultural dynamics that are prevalent in the particular culture in which that philosophy evolved and where the philosopher philosophizes" [22]. The fact that philosophy is a product of culture and philosophers philosophize based on their experiences in their cultural milieu, the reason for many philosophies. This may be the reason why J. O Fasoro argues that:

In the history of philosophy, some (philosophical) theories have come to be identified with some cultures. This is how we can sensibly talk of British empiricism, Continental idealism, American pragmatism, as well as oriental occultism. These philosophies do not exclude anyone from outside the above-mentioned cultures from engaging in them, what we are saying is that the raw data or materials for philosophizing one way or the other were supplied by (or at least were prevalent in) the respective cultures in which these philosophies evolved [23].

In the light of the above, Fasoro further argues that: "This is the more reason why a researcher must be cautious not to make the mistake of interpreting, assessing or evaluating other people's thought in terms of the canons of his cultural understanding" [23]. The point being stressed here is that all philosophies are products of cultures. This point is buttressed by K. C. Anyanwu who opined "there is no such thing as neutral philosophy, therefore the method of studying each culture will differ" [24]. Thus there are various philosophies or philosophical thought systems that arose from different cultures and epochs such as empiricism, idealism, rationalism, existentialism, etc., apart from continental philosophies like Western (Greek) philosophy, Oriental philosophy, African philosophy and so on.

Since rationality is not a native of any part of the world, "there is no part of the world where men never reflect on such basic questions about the human person or about the physical universe and peaceful human existence. In other words, there is no part of the world where men do not philosophize" [15]. It must be stated here that the large freedom permitted in the West especially in Greece, and other parts of the world is responsible for many philosophies, or philosophical systems. Like empiricism, idealism, 
rationalism, and existentialism, etc.

\subsubsection{Philosophy, Culture and Peace}

The emergence of the philosophical systems points to one fact, that the philosophical trends or systems had cultural and epochal backgrounds that pervade the history of philosophy. Thus, every cultural people is capable of philosophizing and capable of raising philosophic questions on their cultural beliefs. The cultural beliefs of a people are usually based on God, gods, man, reality, society and so on which pervaded their language, myths, religions, rites, proverbs, dirges, works of arts, and other cultural phenomena that are innate in them. Hence, C. B. Okolo was very emphatic when he writes: all philosophies are not at the same level of selfdevelopment and since, too, different peoples in different cultures attain different levels of growth in culture, intellectual maturity, leisure, education, etc., they equally attain different levels of philosophical speculation and sophistication. But the ability of rational discourse and consequently of philosophizing is innate in all peoples of all places and of all times [25].

With this background in mind, let us reflect on peace. Peace makes possible the development of culture and philosophy in all civilizations. Philosophy, culture, and peace are germane to human existence and the urban living of people in all epochs. If peace is essential to human existence, development of civilization, culture, and philosophy, what then is peace?

\subsection{Peace}

Longman Dictionary of Contemporary English defines peace as "a situation in which there is no war between countries or in a country... or a period in which there is no war" [16]. Similarly, The New Webster's Dictionary of the English Language [26] defines peace as:

i. The condition that exists when nations or other groups are not fighting

ii. The ending of a state of war the treaty that marks the end of war

iii. Friendly relations between individuals, untroubled by disputes freedom from noise, worries, troubles, fears, etc., peace of mind at peace in a state of peace, friendliness or calm.

The above definitions point to a state of peace which can be interpreted to mean a peaceful state that connotes "calm, quiet, being untroubled, undisturbed by noise, worries, fears or anxieties..." [26]. Peace is a metaphysical concept in the sense that it is a non-tangible phenomenon and a product of a culture of peaceful people. This view may have informed the thinking of Olajide who states that "peace in itself refers to nothing in existence. Because we cannot perceive "peace" except "to say that peace as peace is a situation, a state of affairs" [27]. Peace is a significant phenomenon that gives rise to the development and growth of humans in all ramifications. In the absence of peace in a community or society, or country, there will be no development of any form, especially scientific and technological development. This is the reason why humans crave for peace.

What creates peace among a people in a geographically defined area or society are unity, language, customs, traditions, religion, and philosophy. Culturally, there is no peace in the world because of lack of understanding of the roles of philosophy, culture, and peace by leaders, unequal distribution of natural resources, greed of leaders, exploitation of man, and man's inhumanity to man, and women shunning their traditional role of staying at home to bring up their children in morals and religious ways through didactic stories.

Essentially, peace is a worthwhile phenomenon that enables human beings and especially countries to enjoy the fruits of their labour and their ingenuity. All humans should strive for the acquisition of peace which is regarded as a panacea for happiness. Cultural music festivals is a veritable tool for cohesive and peaceful human existence. Culture and unity are essential tools for the peaceful existence of people with different cultural backgrounds and diversities. In light of the above, culture becomes a veritable tool for social cohesion that promotes peace among human beings.

It is germane to add here that the philosophy and culture of people are positive ingredients that reinforce peace in society. The seven panaceas for peace in society are as follows:

i. The emergency of visionary leaders in the societies.

ii. Eradication of impunity to the lowest level in governance.

iii. The government should encourage the teaching of philosophy, culture, and peace in educational institutions.

iv. The government should be sensitive to the issues and challenges of philosophy, culture, and peace in society.

v. Respect for the constitution of each country and the rule of law.

vi. Parents should devote more time than before to bring up and train the children in proper morals and religious doctrines akin to contemporary values and virtues.

vii.Introduction or organization of sporting activities among the countries in the world, e.g., world cup tournaments or continental/regional sporting activities. These enhance peace.

The concepts of "philosophy", "culture" and "peace" have been examined in this paper from the critical and systematic prescriptive perspective. It has been stated that peace is an essential and necessary ingredient for the development of philosophy and culture in all ramifications. Peace enhances the growth and development of human existence, and consequently the improvement of science, and computer information technology. It has been discovered that there is no peace in some parts of the world because many world leaders do not have a stint and slightest inkling in cultural, peaceful and philosophical ideas, ideals and training. Hence, many leaders do not know the importance of culture, peace, and philosophy to human existence.

With impunity, corruption, and chaos like Boko Haram or terrorism in some parts of the world, intensive studies in philosophy culture, and conflict resolutions should be geared 
towards the sustenance of peace or enduring peace in the world. On this note, one lucid thing is that for societies to develop, no appreciable advancement in human civilization could be made until humans can appreciate the importance of their culture, philosophy and peaceful co-existence.

In other words, without the development of philosophy, culture, and peace in the world, whether in the Hellenic, Roman, Asia or African world, peaceful co-existence among nations would have been a difficult task. The ancient great civilizations, or advancement of humanity in the world, whether Egyptian, Babylonian, Greek, Persian, Chinese, Hellenic, Roman and the Indian flourished due to the native development of culture, philosophy, and peace that existed in their civilizations.

The development of culture, philosophy, and peace are germane to the urban life of people in all epochs. This may be the reason why Jide Osuntokun writes: "But in the real world, urban living has been fundamental to the (peaceful) civilized man's view of culture" [28].

Organisation of philosophical, cultural sport and peaceful events/activities like international seminars and workshops should be a veritable means of promoting peace throughout the world. With a peaceful world, the rate and growth of scientific, technological, religious, computer and information technology will be accelerated.

\section{Concluding Reflections}

The study has been a panoramic role of philosophy, culture, and peace in contemporary society, highlighting that peace is an essential tool of the development of culture, philosophy, and growth of human beings in all ramifications. Also, we have suggested that philosophical, cultural and peaceful events/activities like sports which promotes world peace should be organized among countries of the world, since world peace is expected to promote the existence of human beings, and the development of science, computer information technology would add quality to the human lives in the contemporary world.

Furthermore, efforts have been made here to examine critically philosophy, culture, and peace, the trio concepts widely accepted and none can completely be absent from the life of human beings in any cultural milieu. Thus, philosophy, culture, and peace are the ideal realities that actualize only in the acts of individual human beings in society. That is to say without the acts of men, in terms of their rationality, makes culture, philosophy, and peace possible in the societies.

Culture endows individuals with essential ingredients. For example, culture and peace are essential for the development of personality. Culture and philosophy enable men to realize their freedom and limits in a peaceful society. Man can only achieve personality philosophically, socially and peacefully through the development of his native cultural potentialities. In the contemporary age of science, computer information and technology, people should know that their personality in the society is mainly as a result of their cultural background and philosophical orientation in the peaceful atmosphere.
It needs to be stressed here that the Western cultural realities have eaten deep into the fabric of cultural values and realities and the peaceful existence of the contemporary African cultural system. Thus Western culture "had bastardised the cultural realities of other societies like African to the extent that human beings in African countries are behaving like atomic individuals represent the attempt to sever links with culture, a position which has distorted the basic framework of African (cultural) belief systems (and peaceful co-existence of human beings in the African continent) [27].

In the contemporary world, parents should be encouraged to inculcate moral, religious, cultural and peaceful teachings and doctrines through didactic stories to their children. By doing so, they will be helping to shape a peaceful world through the proper upbringing of children who will be future leaders. In addition to this, the contemporary world leaders should be familiar with the various philosophical, cultural and peaceful nuances of internal and international pressures affecting, or inhibiting, the direction and course of world peace. The progress in the world among the nations depend on the stability and improved governance. There should be a World Peace Leadership Training Institute for Heads of State/ Presidents and Public Office holders where they will be prepared adequately in cultural and philosophical courses for a leadership position with emphasis on peace. Also, the United Nations should encourage warring countries to come together to resolve their problems and offer mutual support. There should be collaboration among countries for a better peaceful future which is expected to enhance the quality of human existence.

It is germane to note the areas of the world where there are (usually) conflicts, terrorism, or civil wars. These areas include Africa, the Middle East, particularly Palestine and Israel, Syria and the consequent refugees' upsurge in the Rohingya from Myanmar. There is no peace in most NorthEastern parts of Nigeria, and the Sahel due to threats to peace posed by the terrorists. Peace may be restored to these warring parts of the world through bilateral relations with intense cultural religious and philosophical studies expected to buttress the thoughts of people on the enhancement of peaceful co-existence.

With great emphasis on the awareness and importance of cultural and philosophical studies towards peace will assist leaders and peoples not to engage in conflicts, terrorism, and wars. This may be in tandem with the recommendation of Plato that, the world may not have peace until rulers become philosophers or philosophers become rulers.

Culture and philosophy as concepts are based on people's deep reflection, imagination, intuitive reasoning and experience to make life meaningful and improve peaceful human existence.

Culture and philosophy, as enunciated earlier in this paper, are developed in the atmosphere where peace reigns supreme and through speculation. Hence, they are products of the human mind. Philosophy is a reflection on the cultural beliefs of a person while culture is a total way of life of a people in 
the society. That is to say that philosophy and culture are intertwined concepts when analyzed, are useful to enhance peace for the overall development of human beings. Without culture a people will be cultureless, a cultureless people are not human beings. Similarly, people without philosophy are not rational beings but mere lower animals that cannot reason. Once people live together within a geographically defined area for a length of time, they are bound to evolve culture and philosophy that will guide their peaceful mode of existence as human beings.

It has been discovered that man, since his existence, has always been animated by cultural beliefs, intuitions, and reflections which give him glimpses of cultural discoveries and peaceful existence which he tries to make means for the development of his human personality. Philosophy helps man to know cultural truth only when it is found in a peaceful atmosphere. Man's rationality in philosophy, culture, and peace makes him hunger for the absolute truth which is part of man's peaceful cultural evolution and growth.

Finally, the Western cultural norms and traditions are fast eroding most of the people's cultural belief systems and values that used to improve the moral standard and uprightness of the people. Thus with computer and scientific technology, Western culture is adversely affecting the mode of thinking and morality throughout the world. Although, we may not necessarily go back to all the cultural norms of the days of yore, but we can substitute or retain some of the stimulating things in the people's cultural values and virtues for the moral edification and peaceful co-existence of the people and youths (future leaders) whose mindsets are polluted against cultural, peace and philosophical systematic training.

\section{Conclusion}

Philosophy and culture of people are positive ingredients which reinforce peace in the society. The paper advocates that people, particularly world leaders, should strive to embrace the training and ideals of philosophy and the culture of peace for the improvement of humans in all ramifications. This is the reason why this paper enumerates the seven panaceas for the enhancement of global peace. Equally, the paper aptly enunciates the importance of peace in the contemporary societies since peace promotes the development of scientific technology, and information technology which enables human beings and countries to enjoy comfort, the fruits of their labour and their ingenuity.

The paper emphasizes that knowledge of philosophy, culture, and peace should strictly be explored to facilitate, not only the progress of the global economy but the development of science and technology which is the life-wire of quality of human existence. Peace is eluding s0me parts of the world mainly because, the leaders in the war-torn-areas do not have iota or slightest inkling in cultural, peaceful philosophical ideas, ideals, and pieces of training. Therefore, many world leaders should strive to know the relevance of culture, peace, and philosophy to human development. This is the reason why the paper recommends intensive studies in philosophy, culture and conflict resolutions as remedies for the sustenance of global peace.

\section{References}

[1] Akeju, O. A. (2010). "The Nature and Scope of Philosophy" in Introduction to Philosophy: A Book of Readings. edited by L. O. Bamikole. Ibadan: AR-RIDAA GRAPHICS. P. 7.

[2] Plato, The Republic.

[3] Descartes Rene, (1911). "Meditation On First Philosophy", in Internet Encyclopedia of Philosophy, trans. By Elizabelth Haldane 1996.

[4] Dewey, J. (1957). Reconstruction in Philosophy, Boston: Beacon Press. P. 2.

[5] Wittgenstein Notes on Early and Late Wittgenstein.

[6] William, J. (1911). Some Problems of Philosophy, New York: Longman Green. P. 5.

[7] Joad, C. E. M. (1944). Philosophy, Great Britain: Teach Yourself Books. P. 16.

[8] Jacquette, 2004: xv Jacquette, Dale (2004). Pathways in Philosophy: An Introductory Reading? Oxford: Oxford University Press. P. 2.

[9] Olatunbosun, D. J. (2012). Fundamentals of Philosophy. Ibadan: Hope Publications.

[10] John Locke's ideas expressed in the Second Treatise of Civil Government.

[11] Bailey, 2002: 4 Bailey, A. (ed) (2002). First Philosophy. New York: Broadview Press. P. 4.

[12] Omolafe, J. A. (1998), "Introduction to Philosophy of Religion" in Philosophy An Anthology, edited by Ayo Fadahunsi. Lagos: Ark Publishers. P. 195.

[13] Makinde, M. (2008). “Awo's Journey to the Philosophical World of Ideas and Reason" an unpublished paper delivered at the remembrance Lecture on Chief Obafemi Awolowo in March 6, 2008, at Ado-Ekiti.

[14] Ogundowole, E. K. (1977). "The Nature of Philosophy, its function in African" a paper delivered at N. P. A Nsukka.

[15] Omoregbe, J. I. (2009). Knowing Philosophy A General Introduction. Lagos: Joja Educational Research and Publishers Ltd. P. 127.

[16] Longman Dictionary of Contemporary English (New Edition) (1995): London: Longman Group Ltd.

[17] Ukpokolo, I. (2004). Philosophy Interrogates Culture. A Discourse in Philosophical Anthropology. Ibadan: Hope Publications. P. 25.

[18] Edwards, P. (1977). The Encyclopedia of Philosophy. New York: Macmillan. P. 275.

[19] Abraham, W. E. (1962). The Mind of Africa, Chicago: The University of Chicago Press. PP. 12-13.

[20] Ademowo, J. A. (2011). Culture, Technology and Human Development in African. Ibadan: Ayomide Publication. P. 8. 
[21] Etuk, Udo (1999), Religion \& Cultural Identity. Ibadan: Hope Publications.

[22] Luzbetak, Louis (1975). The Church and Culture. California: William Carey Library.

[23] Fasoro, J. O. (2002). "The Culture' in Philosophy: A Comparative Analysis of Cultural Influence on the evolution and growth of African and Western philosophies" in Essays in Comparative Philosophy edited by L. O. Bamikole, Ilorin: Majab Publishers. P. 1.

[24] Anyanwu, K. C. (1983). The African Experience in the American Market Place: New York: Exposition Press.
[25] Okolo, C. B. (1987). What is African Philosophy? (A Short Introduction). Enugu: Freemans Press Ltd. P. 8.

[26] The New Webster Dictionary of the English Language (International Edition).

[27] Olajide, Wale (2008). "Conceptualising Peace and Conflict", in Agagu, A. A. Introduction to Peace and Conflict Studies. Ado-Ekiti: University of Ado-Ekiti Press.

[28] Jide Osuntokun, (2018). "Architecture and Urban Development" in The Nation Newspaper, Thursday, $14^{\text {th }}$ June, 2018. P. 14-17. Lagos Vintage Press. 